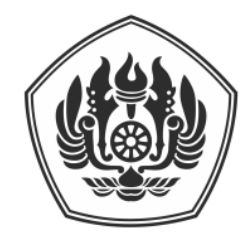

\author{
Padjadjaran Journal of International Law \\ ISSN: 2549-2152, EISSN: 2549-1296 \\ Volume 3, Number 2, June 2019
}

\title{
The United Nations Security Council Resolution on Sanctions Towards Individual from the Perspective of International Law
}

\author{
Jessica Priscilla Suri*
}

\begin{abstract}
The United Nations Security Council (SC) holds the primary responsibility to maintain international peace and security as stipulated in Article 24 of the United Nations Charter (UN Charter). The emergence of international terrorism as a threat to international peace and security encourages the SC to impose sanctions in the form of assets freeze, travel ban and arms embargo towards targeted individuals through the SC Resolutions on Taliban, Al-Qaida and the Islamic State of Iraq and the Levant (ISIL). However, the implementation of UN targeted sanctions towards individuals has been violating the targeted individual's human rights to property, rights of movement, rights to privacy, honor and reputation, and also the rights to a fair trial. This article will explain about the legitimation of the SC Resolutions in imposing sanction towards an individual, and the obligation of UN member states towards the SC resolution that imposes sanctions against its citizen. The violations of human rights stemming from the implementation of SC Resolutions on sanction towards individuals indicate that the resolutions have been adopted beyond the limits of international law. Therefore this condition makes the resolutions lost its legitimacy under international law. In accordance with Article 25 and 103 of the UN Charter, all member states have an obligation to accept, carry on and give priority to the obligation originating from the SC Resolution including to implement the sanction measures towards individuals. Nevertheless, member states must accommodate and harmonize its obligations in respecting, protecting and fulfilling all the individuals' rights who are targeted by the SC along with its obligation to the SC Resolutions.
\end{abstract}

Keywords: Human Rights, Sanction towards Individuals, United Nations Security Council.

\section{Resolusi Dewan Keamanan Perserikatan Bangsa-Bangsa mengenai Sanksi terhadap Individu Menurut Hukum Internasional}

\begin{abstract}
Abstrak
Dewan Keamanan Perserikatan Bangsa-Bangsa (DK) memiliki tanggungjawab utama untuk menjaga perdamaian dan keamanan internasional berdasarkan Pasal 24 Piagam PBB. Munculnya terorisme internasional sebagai ancaman terhadap perdamaian dan keamanan internasional mendorong DK untuk menjatuhkan sanksi berupa pembekuan aset, pelarangan perjalanan serta embargo senjata kepada individu yang ditargetkan melalui rezim Resolusi Taliban, Al-Qaida dan Islamic State of Iraq and the Levant (ISIL). Dalam penerapannya penjatuhan sanksi tersebut menimbulkan pelanggaran Hak Asasi Manusia (HAM) yaitu hak terhadap properti, hak kebebasan berpindah, hak atas privasi, kehormatan dan reputasi serta hak atas proses pengadilan yang adil. Pelanggaran HAM tersebut memunculkan tujuan dilakukannya penulisan artikel ini yaitu untuk menunjukan mengenai legitimasi resolusi DK yang menjatuhkan sanksi kepada individu, serta memaparkan mengenai kewajiban negara anggota PBB terhadap resolusi DK yang
\end{abstract}

PADJADJARAN JOURNAL OF INTERNATIONAL LAW Volume 3 Number 2 Year 2019 [ISSN 2549-2152] [e-ISSN 2549-1296]

Researcher at Lokataru Law and Human Rights Office, Jl. Balai Pustka I No. 14, Rawamangun, Kec Pulo Gadung, Jakarta, Indonesia. jessicapsuri@gmail.com 
menjatuhkan sanksi kepada warga negaranya. Pelanggaran HAM yang disebabkan oleh penerapan penjatuhan sanksi terhadap individu mengindikasikan bahwa resolusi yang mendasari penjatuhan sanksi tersebut diadopsi dengan melampaui batasan-batasan penjatuhan sanksi DK dan telah kehilangan legitimasinya menurut hukum internasional. Sehingga meskipun negara memiliki kewajiban berdasarkan Pasal 25 dan 103 Piagam PBB untuk tetap menerima, melaksanakan dan mengutamakan kewajibannya berdasarkan Resolusi DK yang menjatuhkan sanksi terhadap individu, negara tetap harus mengakomodir dan mengharmonisasikan kewajibannya dalam menghormati, melindungi dan memenuhi HAM individu yang dijatuhkan sanksi saat melaksanakan kewajibannya yang berasal dari Resolusi DK.

Kata Kunci: Dewan Keamanan Perserikatan Bangsa-Bangsa, Hak Asasi Manusia, Sanksi terhadap Individu.

\section{A. INTRODUCTION}

The United Nations (UN) has four main purposes that stipulated in Article 1 of the United Nations Charter (the Charter), and one of them is the purpose to maintain international peace and security. ${ }^{2}$ Through the drafting of the United Nations Charter (the Charter) to create the UN, Dumbarton Oaks Conference agreed that the United Nations Security Council (SC) as the primary organ of the UN would play a role as the core of the envisaged security system, and should possess far-reaching binding powers. Further, this decision was affirmed by the San Francisco Conference. ${ }^{3}$

The powers of the SC under Chapter VII of the Charter are extremely far-reaching and subject to very few express limitations. ${ }^{4}$ Chapter VII of the Charter gives SC the authority to decide when an international 'threat to the peace, breach of the peace, or act of aggression' occurs and what measures should be taken. Article 39 of the Charter have served as the basis for the adoption of wide-ranging mandatory measures against a number of states and non-state entities, ${ }^{5}$ including individuals. In regards to its authority based on Article 39 of the Charter to decide any phenomenon as a threat or breach to the peace and security, international terrorism can thus be seen as the phenomenon where the SC can take forceful actions to eliminate it.

On 15 October 1999, in response to the 7 August 1998 bombings by Osama bin Laden and members of his network against the United States of America Embassies in Nairobi (Kenya) and Dar es Salaam (Tanzania) the SC adopted its Resolution 1267 (1999) that provides sanctions against the Taliban $^{6}$ for the act of terrorism it had done.

Through Resolution 1333 (2000) of 19 December 2000 SC extended the sanctions regime. It was also directed against Osama bin Laden and the Al-Qaeda organization, as well as the Taliban's senior officials and advisers. ${ }^{7}$ Through Resolution 1989 (2011), SC excluded the Taliban from the sanction listing. Move forward to the year of 2015, SC unanimously adopting Resolution 2253 (2015) that expands the sanction framework not only imposing the sanction towards Al-Qaida but also including the Islamic State of Iraq and the Levant (ISIL) also known as Da'esh. ${ }^{8}$

The sanction imposition through the regime of Resolution 1267 (1999) or also

Article 1 United Nations Charter 1945.

Bruno Simma, Mosler Herman, Randelzhofer, Albrech, et al., (eds.), The Charter of the United Nations A Commentary, Second Edition, Volume l, Oxford: Oxford University Press, 2002, p. 703.

Ibid., p. 705.

Vera Gowlland-Debbas, United Nations Sanctions and International Law, The Hague: Kluwer Law International, 2001, p. 1.

Nada v. Switzerland, Judgment, Grand Chamber of the European Court of Human Rights, Application No. 10593/08, 12 September 2012, paragraph. 15.

Ibid., paragraph 17.

\& United Nations, "Unanimously Adopting Resolution 2253 (2015), Security Council Expands Sanctions Framework to Include Islamic State in Iraq and the Levant", 17 December 2015, https://www.un.org/press/en/2015/sc12168.doc.htm, downloaded on 16 November 2017. 
known as the Resolution concerning ISIL (Da'esh), Al-Qaeda and Associated Individuals Groups Undertakings and Entities (ISIL and Al-Qaeda Resolutions) continues and undergoes changes and/or affirmation until recently the SC adopted the Resolution 2368 (2017). In relation to the imposition of sanction towards individual, Paragraph 1 of the Resolution 2368 (2017) states that all states shall take the measures of the asset freeze, travel ban and arms embargo to the ISIL, Al-Qaida and associated individuals, groups, undertakings and entities.

Focusing on the elaboration about the SC sanction towards individuals, the sanction list currently contains the names of 263 individuals and was last updated on 23 August $2018 .{ }^{9}$ The criteria of individuals that are associated with ISIL or Al-Qaida therefore eligible for the inclusion in the ISIL (Da'esh) \& Al-Qaida Sanctions List include: ${ }^{10}$

1. Participating in the financing, planning, facilitating, preparing, or perpetrating of acts or activities by, in conjunction with, under the name of, on behalf of, or in support of;

2. Supplying, selling or transferring arms and related materiel to;

3. Recruiting for; or otherwise supporting acts or activities of AlQaida, ISIL or any cell, affiliate, splinter group or derivative thereof.

Initially, the decision of the SC to impose sanction towards individual was created to correct the failure of the methods of sanction towards states with the aim to give sanction against those that are found to

United Nations Security Council Subsidiary Organs, "Security Council Committee Pursuant to Resolutions 1267 (1999), 1989 (2011) and 2253 (2015) Concerning ISIL (DA'ESH) AL-QAIDA AND ASSOCIATED INDIVIDUALS GROUPS UNDERTAKINGS AND ENTITIES", https://www.un.org/sc/suborg/en/sanctions/1267/aq sanctions list downloaded on 31 October 2017.

10 Ibid.

11 United Nations, Loc.Cit.

12 Noah Birkhäuser, "Sanctions of the Security Council Against Individuals - Some Human Rights Problems", have committed violations to the peace and breach of international peace and security. ${ }^{11}$ However, this decision raises legal issues related to the legitimacy of the UNSC Resolution which imposes sanction towards individuals, as well as the obligations of the member states of the United Nations in respecting, protecting and fulfilling the human rights of the targeted individual.

In relation with the legitimacy of the UNSC resolutions that impose sanction towards the individual, it has to be understood that the whole system of the UN has been conceived to deal with the primary actors in international law: states. ${ }^{12}$ While imposing sanction towards individuals as a form of counter-terrorism actions, the sanction imposed on individuals was not based on the decision of a judiciary body..$^{13}$ Although sanction is a form of policy tool, the freezing of assets clearly restricts a person's right to property, and to do so without informing them or offering the opportunity to challenge the measure arguably violates the right to due process or the right to a fair hearing. ${ }^{14}$ Even the procedures in the sanctions committee contain an elaborate de-listing procedure, but they do not involve persons appearing before the sanctions committee. ${ }^{15}$ As written by Kenneth Manusama while referring to de Wet, the existing procedures and the fact that de-listing requests are reviewed by the sanctions committee through consensus decision-making are, according to de Wet, insufficient to guarantee the individual's fundamental rights. ${ }^{16}$ Reminding that the mandatory decisions of the SC under Chapter VII, are

\footnotetext{
http://www.esilsedi.eu/sites/default/files/Birkhauser.PDF downloaded on 30 October 2017, p. 1.

13 Kenneth Manusama, The United Nations Security Council in the Post-Cold War Era, Applying the Principle of Legality, Leiden: Martinus Nijhoff Publishers, 2006, p. 182.
}

14 Ibid.

15 Ibid.

16 Ibid. 
the outcome of political considerations, not legal reasoning, nor are its proceedings subject to judicial procedures, ${ }^{17}$ then the legitimacy of the $\mathrm{SC}$ resolutions that impose sanctions towards the individual can be questioned.

When the SC directs sanctions against individuals, it has to use the member states as intermediaries. ${ }^{18}$ According to the Member States Report Pursuant to Paragraph 6 of Resolution 1455 (2003) from the year 2003 to 2005 , member states had implemented the sanctions on the individual in accordance with the ISIL \& AlQaida Resolutions and, member states had incorporated and harmonized the resolution with its national law. However, more than 30 legal challenges to the SC targeted sanctions listings had been pursued in courts worldwide. ${ }^{19}$ The defense proposals made by these individuals were entirely based on the premise of fundamental human rights violations. The violations include, among others are the right of movement, the right to privacy, honor and reputation, the right to property, and the right to a fair trial. In contrast, the protection, respect, and the fulfillment of these rights are guaranteed in several international and regional human rights instruments, such as the International Covenant on Civil and Political Rights (ICCPR), Universal Declaration of Human Rights (UDHR) and the European Convention on Human Rights.

Member states are faced with two critical situations: first, the eradication of international terrorism and second prioritizing the protection of the targeted individuals' human rights. There are arguments stated that it is hard to strike a fair balance between protecting human rights and fighting against terrorism. ${ }^{20}$ Thus

17 Verra Gowlland-Debbas, Op.Cit. p. 8.

18 Noah Birkhauser, Op.Cit., p. 2.

19 Thomas J. Biersteker, "Targeted Sanctions and Individual Human Rights", International Journal: Canada's Journal of Global Policy Analysis, Vol. 65 No. 99, 2009., p. 103.

20 R. Wessel, "Debating the 'Smartness' of Anti-Terrorism Sanctions: The UN Security Council and the Individual this research aims to answer about how is the legitimacy of the SC resolution that imposes sanction towards individual in accordance with international law and how is the obligation of UN member states to the resolution that imposed sanctions upon the individual in accordance with human rights law.

\section{B. LEGAL BASIS OF SECURITY COUNCIL SANCTION TOWARDS TARGETED INDIVIDUAL}

As written by Kenneth Manusama while referring to Prof. J. Hallebeek, the Professor of Legal History at the Vrije Universiteit Amsterdam, the $\mathrm{SC}$ is legibus alligatus or in the accurate translation 'bound by law'. ${ }^{21}$ Thus, it is necessary to deliberate about the legal basis of the SC sanction towards the targeted individual, while in this case Article 39 and Article 41 is the most important provisions to determine whether the $\mathrm{SC}$ has the authority to impose sanctions towards the targeted individual that has a connection with the Taliban, Al-Qaida and ISIL. Below is the explanation:

\section{Article 39: Taliban, ISIL, AI-Qaida and} the SC

Since the 1990s the SC came to take part in the increasing efforts of the international community to combat terrorism, through both general statements and concrete action. ${ }^{22}$ Through various SC Resolutions related to Taliban, Al-Qaida and ISIL it can be seen that the SC continuously denounced the existence of international terrorism conducted and supported by Taliban, Al-Qaida, and ISIL. Although international lawyers and scholars have been able to define terrorism, the SC as the strongest

Citizen" in Legal Instruments in the Fight against International Terrorism: A Transatlantic Dialogue, compiled by C. Fijnaut, J. Wouters dan F. Naert (eds.), Leiden: Martinus Nijhoff Publishers, 2004, p. 659.

21 Kenneth Manusama, Op.Cit., p. 45.

22 Ibid. 
political body in the world had taken concrete step to combat international terrorism because simply, in accordance with Article 39 of the Charter the SC enjoys broad discretion in assessing what constitutes the threat to international peace and security. But we must understand that international terrorism, in general, creates severe destabilizing effects on the international order. ${ }^{23}$

Al-Qaida led by Usama bin Laden is known as a terrorist organization that had made several terrorist attacks. Started from 7 August 1998, where AlQaida attacked the Embassy of the United States in Nairobi, Kenya and Dar es Salaam, Tanzania, until the bombing in New York, Washington D.C and Pennsylvania on 11 September 2001 (9/11), the SC declared those actions as a threat to the international peace and security. In the other side, there is Taliban a faction in Afghanistan Civil War that was found providing sanctuary and training to Al-Qaida in its territory, its silence and its support for Al-Qaida was denounced by the SC as a threat to the international peace and security. Recently, ISIL presents as a new threat to the international peace and security.

ISIL rebels have started a new insurgency war, launching suicide attacks. ${ }^{24}$ Related to ISIL, in 2013, terrorist attacks killed, maimed, and displaced thousands of civilians from Afghanistan to Somalia to Nigeria, from Iraq to Libya. The 'Annual Threat Assessment 2016' covers the forecast of the terrorist threats to various regions from Southeast Asia to Central and East Asia, from the Middle East to South Asia and from Africa to South America. Some

Ibid.

24 Joel Mwangi Kihanga, "Islamic State as a Threat to Global Peace and Security: an Analysis of the Mechanisms used by th International Community, $<$ http://erepository.uonbi.ac.ke/bitstream/handle/112 95/94594/Kihanga Islamic\%20state\%20as\%20a\%20thr eat\%20to\%20global\%20peace\%20and\%20security:\%20 of the high-profile terrorist attacks claimed by the ISIL in 2016 outside Iraq and Syria, included the bombing that happened in Istanbul, Belgium, France and Kabul. ${ }^{25}$ Further, most Southeast Asian countries such as Indonesia, Malaysia and the Philippines, which were facing terrorism by traditional groups, are now also threatened by the increasing involvement of the ISIL in the region. ${ }^{26}$

Again, as the strongest political body in the world, The SC could not stay silent to the emergence of international terrorism conducted and/or supported by Taliban, Al-Qaida and ISIL that is proven threatening international peace and security. So that, the SC through Resolution No. 2253 (2015) reaffirming that terrorism in all forms and manifestations constitutes one of the most serious threats to peace and security and that any acts of terrorism are criminal and unjustifiable regardless of their motivations, whenever, wherever and by whomsoever committed. In the different issues concerning terrorism, the role of the SC is primarily circumscribed, of course, by the responsibilities and powers granted to it by the Charter. ${ }^{27}$ Thus, the SC has the authority to act in accordance with Chapter VII of the UN Charter to eliminate the act of international terrorism conducted by Taliban, AlQaida and ISIL.

\section{Article 41: Targeted Individual and the} SC

Targeted individual sanctions is a new form of the SC practice in imposing sanction measure. Article 41 of the UN Charter also give the $\mathrm{SC}$ a wide space to

an.pdf?sequence $=2>$ downloaded on 17 October 2018, p. 9.

25 Muhammad Munir dan Muhammad Shafiq, "Global Threat: A Comparative Analysis of Al-Qaeda and the Islamic State", IPRI Journal, Vol. XVI, No. 2., 2016., p 12.

26 Ibid.

27 Kenneth Manusama, Op.Cit., p. 102. 
act with flexibility in determining what measures should be imposed on each different case. Further, the SC has the authority to make a discretion on pointing the target that will be sanctioned. ${ }^{28}$ So that based on the broad authority of the SC that stipulated in the UN Charter, it can be justified that SC through its interpretation has the authority to impose any kinds of sanctions to any subject that threatens international peace and security as long as the SC itself acts within the limitations ruled by the UN Charter.

\section{Limitation to SC Sanction}

The broad discretion of the SC to consider whether a situation constitutes international peace and security has limitations. There are principles that limits the SC in implementing measures that is in accordance with the existing norm that exist within the Charter or international law in general. Here are some of the principles that limits the imposition of SC sanctions:

\section{a) Proportionality Principle}

Article 39 and Article 41 of the Charter is the legal basis that determine the imposition of sanction must be in accordance with the principle of proportionality. This principle was meant to make sure that any action taken by the SC is necessary to remove threats to peace and international security. According to this principle, Chapter VII measures would therefore violate the Charter only if their impact were manifestly out of proportion to the aims pursued. ${ }^{29}$

\footnotetext{
28 Jeremy Matam Farrall, United Nations Sanctions and the Rule of Law, New York: Cambridge University Press, 2007., p. 106.

29 Bruno Simma, et al (eds.)., Op.Cit., p. 712.
}

\section{b) The Principle of Limited Powers}

The SC, as any other organ of an international organization, enjoys powers only insofar as they are conferred on it by or implied in the constituent instrument of the Organization. ${ }^{30}$ While it is true that every organ must, in the first place, determine its own jurisdiction, such a determination is binding only if supported by the member States in general. ${ }^{31}$

c) Purposes and Principles of the UN

Article 24 paragraph (2) of the Charter is acting as the legal basis which obligated the SC to take any action in accordance with the purposes and the principles of the UN itself. One of the purpose and principle of the UN is stipulated in the Article 1 paragraph (3). Article 1 paragraph (3) of the Charter take role as a guideline for the SC in making any measurement towards certain entity or individual. The SC's complete disregard for them (the purposes and principles of the UN) would violate the Charter. ${ }^{32}$

\section{AFFECTED HUMAN RIGHTS}

As previously mentioned in part $A$, there are several human rights that were violated by the implementation of the SC sanctions towards the individual. The most known legal challenge regarding these matters are, the case of Mohammed Jabar Ahmed et al., v. Her Majesty Treasury in the United Kingdom Supreme Court on 2010, Abousfian Abdelrazik $v$. the Minister of Foreign Affairs and the Attorney General of Canada in the Federal Court of Canada on 2009, Yassin Abdullah Kadi and Al Barakaat International Foundation v. the Council and Commission of the European Union in European Court of Justice, and Nabil Sayadi

\footnotetext{
Ibid., p. 710

Idem.

32 Ibid., p. 711.
} 
and Patricia Vinck v. Belgium in the United Nations Human Rights Committee on 2008. Below is the short explanation of each case that stated that the human rights of the targeted individuals are being affected by the sanction implementation.

First, are the rights of movement, the rights of movement are known to be affected by the implementation of travel ban sanction. The evidence that the rights of movement is being affected by the sanction implementation is supported by the fact that the United Nations Human Rights Committee (UNHRC) gave a statement that the restriction of the rights of movement of Nabil Sayadi and Patricia Vinck were not necessary to protect national security or public order thus Belgium was violating Article 12 of the ICCPR. ${ }^{33}$ Federal Court of Canada also stated that the implementation of the travel ban sanction from SC Resolution No. 1267 (1999) was violating Article 6 Paragraph (1) 34 of Canadian Charter of Rights and Freedom (Canadian Charter). ${ }^{35}$

Second, is the rights to property, the rights to the property are known to be affected by the implementation of asset freeze sanction. The evidence that there was a violation of the rights to property is supported by the fact that in the case of Yassin Abdullah Kadi and Al-Barakaat International Foundation v. Council of the European Union (CEU) and Commission of the European Communities (CEC) in front of the Court of Justice of the European Union (CJEU). CJEU stated that the restriction to Yassin Abdullah Kadi's rights to his property without any guarantee that enables him to

33 Nabil Sayadi and Patricia Vinck v. Belgium, Views, United Nations Human Rights Committee, CCPR/C/94/D/1472/2006, 29 December 2008, paragraph 10.8 .

34 Article 6 paragraph (1) of Canadian Charter of Rights and Freedoms 1982.

35 Abousfian Abdelrazik (Applicant) v. Canada (Minister of Foreign Affairs and the Attorney General of Canada) (Respondent) (Abousfian Abdelrazik v. Canada), Judgment, Federal Court of Canada, 2009, F.C.J. No. 656, 4 June 2009, paragraph 169.

36 Yassin Abdullah Kadi (Applicant) v. Council of the European Union and Commission of the European put his case to the competent authorities constitutes an unjustified restriction of his right to property. ${ }^{36}$ In the Decision of the United Kingdom Supreme Court to the case of Mohammed Jaber Ahmed, et al., Mohammed al-Ghabra and Hani El Sayed Sabaei Youssef v. Her Majesty Treasury, Lord Hope followed by Lord Walker and Lady Hale stated that in this case there are two human rights violations that happened, and one of them is the rights to property. ${ }^{37}$

Third, is the rights to privacy, honor and reputation, these rights are affected by the publication of the online list of all targeted individual's name that can be accessed freely from around the world at the UN website with the titled "The Consolidated List established and maintained by the 1267 Committee with respect to Al-Qaida, Usama Bin Laden, and the Taliban and other individuals, groups, undertakings and entities associated with them." The publication of their name in the sanction list has led to interference in their private life and unlawful attacks on their honour and reputation. The affirmation that there is a violation to these rights are stated by the UNHRC when it said that Belgium should be held responsible for the presence of their names on the United Nations sanctions list, which has led to interference in their private life and unlawful attacks on their honour and reputation. ${ }^{38}$

Fourth, is the right to a fair trial, while states are implementing the sanctions, several individuals had proposed the review of sanction implementation to the national, regional and international court or committee because the targeted individuals

Communities (Respondent), Judgment, European Union Court of First Instance, T-315/01, (Kadi Case), 2009, paragraph 368-369.

37 Her Majesty's Treasury (Respondent) v. Mohammed Jabar Ahmed and others (FC) (Appelants), Her Majesty's Treasury v. Mohammed al-Ghabra (FC) (Appelant), (Respondent), R (on the application of Hani El Sayed Sabaei Youssef) (Respondent) v. Her Majesty's Treasury (Appellant), Judgment, United Kingdom Supreme Court, [2008] EWCA Civ 1187 (further be written HMT v. Ahmed and others), 27 January 2010, paragraph 75.

38 Nabil Sayadi and Patricia Vinck, Op.Cit., paragraph 10.13 
perceived that there are violations to the human rights to a fair trial. In this case, Yassin Abdullah kadi argued that his right to be heard had been violated by the EC Regulations because it had implemented the sanction without any procedure that can prove that $\mathrm{He}$ is connected with the terrorist activity. CJEU stated that: ${ }^{39}$

"Because the Council neither communicated to the appellants the evidence used against them to justify the restrictive measures imposed on them nor afforded them the right to be informed of that evidence within a reasonable period after those measures were enacted, the appellants were not in a position to make their point of view in that respect known to advantage. Therefore, the appellants' rights of defence, in particular the right to be heard, were not respected."

In its judgment of 4 June 2009 in the case of Abousfian Abdelrazik v. Canada, the Federal Court of Canada took the view that the listing procedure of the al-Qaeda and Taliban Sanctions Committee was incompatible with the right to an effective remedy. ${ }^{40}$ In the other side, different from the previous decision, UNHRC considers that this sanction implementation does not concern a "criminal charge" in the meaning of Article 14, paragraph 1. The Committee, therefore, finds that the facts do not disclose a violation of Article 14, paragraph 3 , Article 14, paragraph 2, or Article 15 of the International Covenant of Civil and Political Rights (ICCPR) or in short the rights to a fair trial. ${ }^{41}$

\section{LEGITIMACY OF "THE RESOLUTION"}

Article 24 paragraph (1) of the UN Charter states that in carrying out its duties, the SC can act on behalf of the UN members. ${ }^{42}$ Thus all of the decision of the SC must be taken in accordance with the existing law to protect the legitimate interest of every UN member states. ${ }^{43}$ It also appears to be in the SC's interest to base its decisions on the principles and rules of international law, so as to foster the acceptance of these decisions by the 'target' entity (the entity whose behaviour constitutes a threat to international peace and security), as well by the UN Members in general. ${ }^{44}$ If the decision or the resolution of the SC is not in accordance with the applicable legal limits, the decision or action imposed by the SC will lost its legitimacy, because the legitimacy of a decision or action depends heavily on state consent to the decision or action.

As previously deliberated in part $B$, the SC appears to act legally because Article 39 and 41 of the UN Charter give space for the $\mathrm{SC}$ to impose sanctions in the form of asset freeze, travel ban and arms embargo to all listed individual that directly or indirectly support the international terrorism conducted by Taliban, ISIL and Al-Qaida. However, due to the several human rights issues as mentioned in part $\mathrm{C}$, then the legitimacy of the $\mathrm{SC}$ resolution that imposes sanctions to individuals can be questioned. However, in terms of the outcome of court decisions to date, challenges to the competence and authority of the SC to make such designations have not succeeded..$^{45}$ Instead, the state's policy that implements the SC resolution that is reviewed by the courts.

The UN is an international organization that upholds the value of respecting human rights and it is stipulated in the UN Charter. The statements made by the court or even UNHRC that said there is violation to human

42 Bruno Simma et al (eds.), Op.Cit., p. 446.

43 Verra Gowwland-Debbas, Op.Cit., p. 71.

44 Ibid.

45 Ibid., p. 104
39 Kadi Case, Op.Cit., paragraph 348.
$40 \quad$ Nada v. Switzerland, Op.Cit., paragraph 98.

41 Nabil Sayadi and Patricia Vinck, Op.Cit., paragraph 10.11 . 
rights instruments in the national, regional and international level as a cause of the implementation of SC targeted sanctions is proof that whether directly or indirectly, the SC resolutions that impose sanctions towards individual have probably violated the principles in international law that limits the sanction imposition as previously agreed by the UN Member States and those are the principles of limited power, proportionality principles and the purposes and principles of the UN itself.

According to the principles of limited power, the first thing that we have to know is that the SC has broad discretion in the choice of measures. ${ }^{46}$ It is also true that every organ must, in the first place, determine its jurisdiction, ${ }^{47}$ but such determination is binding only if supported by the member States in general. In this case, some UN member states have indicated a growing reluctance to add names to the lists of individuals and entities targeted by security council sanctions because of human rights concerns, and more than 50 member States have expressed concern about the lack of due process and absence of transparency associated with listing and delisting. ${ }^{48}$ Two of the permanent members of the SC, France and the United Kingdom (UK), agreed that some reform to the listing and delisting procedures might be considered. ${ }^{49}$ As a result of these deficiencies, some UN member states argued that major reforms were necessary and that the issue created a potential challenge to the legitimacy of the security council itself. ${ }^{50}$

Not only adopted beyond the principle of limited powers, the imposition of sanctions towards individual had also adopted in contrast from the purposes and the principles of the UN, particularly the purpose in promoting and encouraging respect for human rights and for fundamental freedoms which are stipulated in the Article 1 paragraph (3) of the UN Charter. The implementation of SC sanctions toward targeted individuals was found affecting individual human rights to movement, property, privacy, honor and reputation and the rights to a fair trial. On 19 September 2005, the General Assembly of the UN had adopted Resolution No. 60/1, where all the Heads of States urged the SC with this statement:

\section{"call[ed] upon the Security Council} with the support of the Secretary General to ensure that fair and clear procedures exist for placing individuals and entities on sanctions lists and for removing them, as well as for granting humanitarian exemptions."

The present situation illustrated a "denial of legal remedies" for the individuals and entities concerned, and is untenable under principles of international human rights law: "Everyone must be free to show that he or she has been unjustifiably placed under suspicion and that therefore [for instance] the freezing of his or her assets has no valid foundation." ${ }^{51}$

Moreover, the imposition of sanctions towards individual was also adopted beyond the principle of proportionality. The unfair procedures of listing the names of the targeted individual affecting the rights of many individuals that did not involve in the activity of Taliban, Al-Qaida and ISIL. The case of Abdelrazik for instance, on 12 September 2003, Mr. Abdelrazik was arrested by the Sudanese authorities without any charge but only based on suspicion, which the Sudanese officials recognized that this action violated his

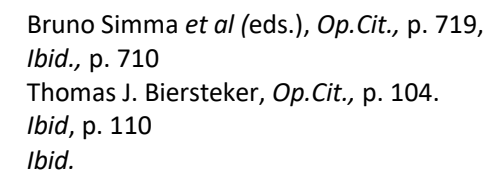

51 Bardo Fassbender, "Targeted Sanctions and Due Process", Office of Legal Affairs, Institute of International European Law, Humboldt University Berlin, 20 Maret 2006, p.5, http://www.un.org/law/counsel/Fassbender study.pdf 
human rights. ${ }^{52}$ In the case of Mohammed Jabar Ahmed, et al., Mohammed al-Ghabra and Hani El Sayed Sabaei Yousseff v. Her Majesty Treasury in the United Kingdom Supreme Court, A, K, M, G, and HAY stated that the implementation of the SC sanctions also affects third parties too, including the spouses and other family members of those who have been designated. ${ }^{53}$ Citing the statement of the ICJ in United States Diplomatic and Consular Staff in Tehran case:

"Wrongfully to deprive human beings of their freedom and to subject them to physical constraint in conditions of hardship is in itself manifestly incompatible with the principles of the Charter of the United Nations, as well as with the fundamental principles enunciated in the Universal Declaration of Human Rights."

The imposition of sanctions on individuals who are not eligible to be sanctioned because of an unfair process and causing severe economic and social impacts on the family of the targeted individuals is violating the principle of proportionality because it can be considered as an action that is not necessary to remove threats to peace and international security.

Based on the aforementioned arguments, it can be concluded that the resolution that imposes sanction towards an individual is a resolution that is adopted beyond the legal limitation of the UN sanctions and therefore could be considered as an ultra vires resolution, and a decision taken ultra vires is not binding. ${ }^{54}$ This condition could make the ISIL and AlQaida resolution that imposes sanction on individual lost its legitimacy under international law.

Abousfian Abdelrazik v. Canada, Op.Cit., paragraph 13

53 HMT v. Ahmed and others, 27 January 2010, Op.Cit., paragraph 35 .

54 Nabil Sayadi and Patricia Vinck v. Belgium, Op.Cit., paragraph 5.7 .
Kenneth Manusama wrote this statement in his book:

"The Council appears to act legally, but finds less and less legitimacy in doing so, moving towards a kind of 'illegitimate legality'."

Although the imposition of sanction towards individual was based on the SC's authority that stipulated in the UN Charter, legality is not always on the same page as legitimacy. ${ }^{55}$ The imposition of sanctions towards an individual is based on its authority under Article 39 and 41 of the UN Charter and it reflects the statement of Kenneth Manusama that "the council appears to act legally". Some court decisions both at the national, regional and international levels decided not to implement the sanctions due to human rights matters. The condemnation of the international community due to human rights violations stemming from the imposition of SC sanctions illustrated that the SC "finds less and less legitimacy and moving towards a kind of 'illegitimate legality."'

International law limits the SC's powers in many ways, without however affecting the efficiency of its action. ${ }^{56}$ Moreover, international law itself makes it possible to take account of the special circumstances which the SC often invokes to justify its action under Chapter VII of the Charter. ${ }^{57}$ However, the SC needs to reform the sanctions implementation procedures as requested by the international community, and this could be done by reffering to legal principles which are accepted by all the UN Members, as this could be used as the best means for the Council to foster the legitimacy of its decision. ${ }^{58}$

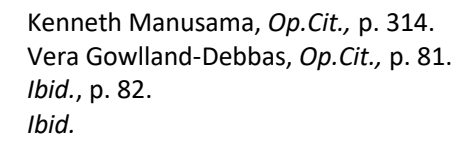




\section{E. MEMBER STATES OBLIGATION TO SC RESOLUTIONS AND HUMAN RIGHTS PROVISION}

Due to the problem of human rights violations arising from the implementation of the $\mathrm{SC}$ resolution as previously explained, the UN member States are faced with two obligations, the first is the obligation to comply with the SC Resolution and the second is the obligation to comply with human rights law. The following is an explanation to the question of how is the UN member States obligations to the SC resolution that impose sanctions on its citizens in accordance with international human rights law.

\section{Member States Obligation to SC Resolutions}

The member States of the UN have certain rights and obligations given by the UN Charter, and one of them is the obligation to accept and carry on the decision of the SC.59 The SC Resolutions though cannot be considered as being among the sources of international law set out in the Article 38 paragraph (1) of the International Court of Justice Statute (ICJ Statute), ${ }^{60}$ but it only means that the SC can create rights and obligations for member States of the UN. ${ }^{61}$ Further, the rights and obligations created by the SC resolution can override those derived from treaties in accordance with Article 103 of the UN Charter. ${ }^{62}$ However, the relief which Article 103 of the UN Charter may give the SC in case of conflict between one of its decisions and an operative treaty obligation cannot - as a matter of simple hierarchy norms - extend to a

59 Article 25 of the UN Charter 1945.

60 Marc Perrin de Brichambaut, "The Role of the United Nations Security Council in the International Legal System", in The Role of Law in International Politics, compiled by Michael Byers, Oxford: Oxford University Press, 2000. p 269.

61 Ibid.

62 Ibid., p. 274. conflict between the $\mathrm{SC}$ resolution and jus cogens. ${ }^{63}$

In relation with the discussion about the obligations of UN member States to the SC Resolutions that impose sanctions towards the individual, as stated by the ICJ in the Namibia Advisory Opinion 1971,

"The language of a resolution

of the Security Council should

be carefully analyzed before a conclusion can be made as to its binding effect..."

To decide whether the ISIL and AIQaida Resolutions have binding effects, the resolutions have to contain or refers to an Article 39 determination, and includes the words "acting under Chapter VII" or reference to an appropriate article thereof, as well as the word "decides" to be mandatory ${ }^{64}$ In the preamble of the ISIL and AI-Qaida Resolutions, the SC wrote down "Acting under Chapter VII of the Charter of the United Nations." This is an affirmation that the actions of the SC are based on the provisions in Chapter VII of the UN Charter. Further, in the a quo resolution, the used the term "decides that all States shall take the following measures..." while imposing a sanction against the individual. Both statements annunciate that the provisions stipulated in the ISIL and Al-Qaida Resolutions are mandatory to The UN Member States.

\section{Member States Obligations to Human} Rights Provisions

Human rights correspond to obligations borne by the state, which can be categorized as duties to respect, to

63 Malcolm N. Shaw, International Law (Sixth Edition), New York: Cambridge University Press, 2009, p. 127.

64 Michael C. Wood, "The Interpretation of Security Council Resolutions", Max Planck Yearbook of United Nations Law, p. 82, http://www.mpil.de/files/pdf2/mpunyb_wood 2.pdf downloaded on 16 October 2018. 
protect and to fulfill. ${ }^{65}$ The law of international human rights also recognized a principle. In accordance with the decisions of the United Kingdom Supreme Court, Federal Court of Canada, Court of Justice of the European Union and the United Nations Human Rights Committee, even if the conflict of obligations arising from the SC resolution and human rights provision is the main argument between State parties and the targeted individual of each case, the courts and the committee does not consider the problem the same way.

First, in relation to the conflict between the rights of movement and travel ban sanction. Basically the rights of movement are not considered as absolute rights. In accordance with Article 12 paragraph 3 of ICCPR, member States could restrict an individual's rights to movement which is necessary to protect national security or public order, the obligations from SC resolution that is adopted under Chapter VII of the UN Charter may constitute a "restriction" that is necessary to protect national security or public order. However, the unfair procedure that is implemented by the member States of the UN made the restriction of the rights of movement as an order from the SC sanctions invalid.

Second, is the issue of the conflict between the rights to property and asset freeze sanction, just the same as the rights of movement, the rights to the property is not an absolute right, but the restriction to this rights must be in accordance with the existing law. ${ }^{66}$ In relation with the judges' statement on the case of HMT v. Ahmed and others, and the Kadi case, the procedure that is

65 Inga T. Winkler, "Respect, Protect, Fulfill: the Implementation of the Human Right tot Water in South Africa, p. 423, https://www.ingawinkler.com/uploads/4/8/6/0/48601 $803 /$ respect protect fulfill.pdf downloaded on 16 October 2018. implemented by member States of the UN in implementing the SC sanction towards individual made the restriction to the rights to property invalid. ${ }^{67}$ Lord Hope in the decision of United Kingdom Supreme Court to the case of Mohammed Jaber Ahmed, et al., Mohammed al-Ghabra dan Hani El Sayed Sabaei Youssef v. Her Majesty Treasury, stated that:

"...the right to peaceful enjoyment of his property, which could only be interfered with by clear legislative word, Fundamental rights may not be overridden by general words. This can only be done by express language or by necessary implication..."

$\mathrm{ECJ}$ also stated that: "It follows from all those considerations that the obligations imposed by an international agreement cannot have the effect of prejudicing the constitutional principles of the EC Treaty, which include the principle that all Community acts must respect fundamental rights, that respect constituting a condition of their lawfulness which it is for the Court to review in the framework of the complete system of legal remedies established by the Treaty."

Based on these two statements, even international agreements cannot directly limit a person's right to his property because the limitation must be based on the existing rules, and those who apply such restrictions must

\footnotetext{
66 Janusz Symonides (eds.), Human Rights: Concept and Standards, Aldershot: Ashgate Publishing Ltd., 2000, p. 101. 67 Kadi Case, Op.Cit., paragraph 281. See also HMT v. Ahmed and others, Op.Cit., paragraph 250.
} 
be fully authorized to limit the fundamental rights of an individual.

The third, is the conflict between the obligations to fulfill the individual's rights to privacy, honor and reputation and the obligations to give the names of all individuals related to Taliban, AlQaida and ISIL to the Sanction Committee where all the names will be uploaded to the $\mathrm{SC}$ website that can be accessed from around the world. The right to privacy, honor and reputation is not an absolute right, but state interference with the right in an arbitrary and illegitimate manner is something that is not desired. ${ }^{68}$

Fourth, is the right to a fair trial, in the conflict between the obligation of the state to apply SC sanctions to individuals and the fulfillment of individual rights to a fair trial process, the state must still fulfill its obligations to individual human rights to get a fair trial that guaranteed by national, regional and international human rights instrument even though the country is undergoing other international obligations, for example, SC Resolution. This is because the principle of a fair trial is a means of guaranteeing citizens' trust in the jurisdiction of a country that is based on law and not impartial. ${ }^{69}$

The statements of the aforementioned institutions illustrated that the core problems in this matter is the procedure of the implementation of SC sanction towards the individual. This statement is motivated by the fact that even the individual's rights that are being violated by the sanction implementation is not categorized as a jus cogen norms, ${ }^{70}$ the procedure to implement the SC sanction towards individual emerges violations to the

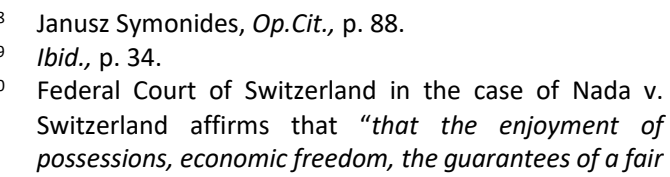

targeted individual's fundamental rights.

From the explanation above, then how is the member States' obligation to the SC Resolution that imposes sanctions on individuals in accordance with international human rights law? To answer this question, citing from the dissenting opinion to the case of Nabil Sayadi and Patricia Vinck v. Belgium from Mr. Ivan Shearer as the committee member of the UNHRC, he stated that human rights law must be accommodated within, and harmonized with, the law of the Charter as well as the corpus of customary and general international law, ${ }^{71}$ so that the purpose of the UN to maintain international peace and security that concern the obligation to respect, protect and fulfill the human rights of the targeted individual will be accomplished.

In balancing the obligations stemming from the UN Charter in order to maintain international peace and security as well as those originating from human rights law, member States of the UN may carry out certain efforts first is to conduct the legal action to respect, protect and fulfill the targeted individuals' human rights. Second, it must also fulfill its responsibility under existing human rights provision to fulfill the human rights of the targeted individual.

First, to fulfill the obligation to respect, UN member States must establish a procedure whereby individual human rights restrictions imposed by sanctions must be based on clear legal rules and enforced by the competent authority. Second, based on the state's obligation to protect the targeted individuals' human rights, member State can conduct a procedure

trial or the right to an effective remedy did not fall within jus cogens." In Nada v. Switzerland, Op.Cit., paragraph 47.

71 Nabil Sayadi and Patricia Vinck v. Belgium, Op.Cit., p. 32. 
that is in accordance with the principle of due process law while implementing the SC Resolutions that impose sanctions to the individuals.

If the member states of the UN can implement the imposition of SC sanctions through an appropriate legal process, then this action may prevent unwanted human rights violations to the targeted individual. Thus, if the UN member states can implement their obligations in respecting and protecting the targeted individual human rights, then the member States of the UN have fulfilled its obligation to fulfill the human rights of the targeted individuals.

If human rights violations had occurred, member States must take responsibility for the human rights violation due to the implementation of SC Resolutions that impose sanction towards the individual. Based on the cases mentioned before, the right to an effective remedy is a form of responsibility desired by the court to be applied by the state due to human rights violations that occurred. The rights to an effective remedy are actually guaranteed in Article 8 of the UDHR:

"Everyone has the right to an effective remedy by the competent national tribunals for acts violating the fundamental rights granted him by the constitution or by law."

The UDHR offers a wide range of the right to an effective remedy, since it does not limit the scope to the fundamental rights listed in the ICCPR, but as long as it exists in national law. ${ }^{72}$ The state responsibility to give the rights to an effective remedy may depend on the policy of the

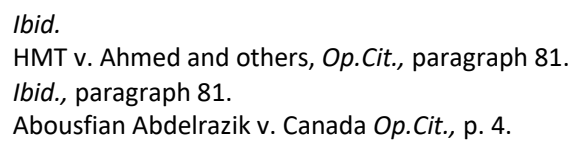

government itself based on the applicable law. The various kinds of effective remedy can be illustrated from the decision of the UK Supreme Court, Federal Court of Canada and the UNHRC.

In the case of Mohammed Jabar Ahmed, et al., Mohammed al-Ghabra, and Hani El Sayed Sabaei Youssef v. Her Majesty's Treasury, the UK Supreme Court give $\mathrm{G}$ the effective remedy due to the violation of his rights that is guaranteed under Article 6 (1) of the Human Rights Acts 1998 because of the listing of his name by the Sanction Committee. ${ }^{73}$ In the judgment, Lord Hope stated that: ${ }^{74}$

"What he needs if he is to be afforded an effective remedy is a means of subjecting that listing to judicial review."

In the case of Abousfian Abdelrazik v. Canada, he had given the right to an effective remedy in the form of an emergency passport that allows him to fly back to Canada. ${ }^{75}$

In the case of Nabil Sayadi and Patricia Vinck v. Belgium, the UNHRC decided that Belgium is bound to provide Nabil Sayadi and Patricia Vinck with an effective remedy. The effective remedy could be done through doing all it can to have Nabil Sayadi and Patricia Vinck removed from the list as soon as possible, to provide them with some form of compensation and to make public the requests for removal. ${ }^{76}$ Further, pursuant to Article 2 of the Covenant, the State party has undertaken to ensure to all individuals within its territory and subject to its jurisdiction the rights recognized in the ICCPR and to provide an effective and enforceable remedy when a violation is found to have occurred. ${ }^{77}$
76 Nabil Sayadi and Patricia Vinck v. Belgium, Op.Cit., paragraph 12 .

77 Ibid., paragraph 13. 
Through the practices mentioned earlier, the fulfillment of the right to effective remedies is the most common form of state responsibility ordered by the courts for human rights violations that occur as a result of the implementation of SC sanctions towards individuals. So the state can carry out its responsibilities through the fulfillment of the right to effective remedies, which forms may vary according to what is needed and based on applicable law.

\section{F. CONCLUSION}

The implementation of sanctions towards individual through the regime of Taliban, AlQaida and ISIL Resolutions was based on Article 39 and 41 of the UN Charter. However the procedure of sanction implementation by the SC or even by member states is violating the fundamental human rights of the targeted individuals, and those are the rights to property, rights of movement, rights to privacy, honor and reputation, and also the rights to a fair trial. The violation of the mentioned rights in the national level or at the UN level had made the SC resolution that imposes sanctions towards individual was adopted beyond the principle of limited power, proportionality principle, and even the purposes and principle of the UN especially as stipulated in the Article 1 paragraph (3) of the UN Charter about the respect of individual human rights. Therefore the imposition of sanctions towards individual through the regime of Taliban, Al-Qaida and ISIL Resolution has lost its legitimacy. Despite that, the member states of the UN still have to accept, carry on and prevailing the obligation stemming from the SC Resolution as command by Article 25 and 103 UN Charter, but the adherence to the obligation from the SC Resolution should also accommodate and harmonize the obligation to respect and protect the human rights of the targeted individuals.
For the aforementioned problems, the author proposes several recommendations; First, the member states of the SC must review and change the procedure of sanction implementation in the UN level for the resolution to get its legitimation back.

The procedure must consider the demand of the international community and that is to take account the legal principle recognized by the UN and that is the principle of limited power, proportionality principle and the purposes and principles of the UN itself which one of them is the principle to respect the individual fundamental human rights. Second, while fulfilling its obligation under the UN Charter in accordance with Article 25 and 103 of the UN Charter and that is to accept, carry on and prevailing SC Resolution, member states of the UN must balance it with the obligation stemming from human rights legal instruments. This could be done by carrying out efforts to protect the targeted individual's human rights and fulfill its responsibilities towards the violation of human rights due to the implementation of the SC sanctions.

\section{REFERENCES}

\section{Books}

Byers, Michael, (eds.), The Role of Law in International Politics, Oxford University Press, Oxford, 2000.

Farrall, Jeremy Matam, United Nations Sanctions and the Rule of Law, Cambridge University Press, Cambridge, 2007.

Fijnaut, C., Wouters J., and Naert, F. (eds.), Legal Instruments in the Fight against International Terrorism: A Transatlantic Dialogue, Martinus Nijhoff Publishers, Leiden, 2004.

Gowlland-Debbas, Vera, United Nations Sanctions and International Law, Kluwer Law International, The Hague, 2001.

Manusama, Kenneth, The United Nations Security Council in the Post-Cold War Era, Martinus Nijhoff Publishers, Leiden, 2006. 
Shaw, Malcolm N., International Law (Sixth Edition), Cambridge University Press, New York, 2009.

Simma, Bruno, Mosler, Herman, Randelzhofer, Albrecht, et al., (eds.) The Charter of the United Nations a Commentary, Second Edition, Volume I, Oxford University Press, Oxford, 2002.

Symonides, Janusz, (eds.), Human Rights: Concept and Standards, Ashgate Publishing Ltd., Aldershot, 2000.

\section{Other Documents}

Biersteker, Thomas J., "Targeted Sanctions and Individual Human Rights", International Journal: Canada's Journal of Global Policy Analysis, Vol. 65 No. 99, 2009.

Birkhäuser, Noah, "Sanctions of the Security Council Against Individuals - Some Human Rights Problems", <http://www.esilsedi.eu/sites/default/files/Birkhauser.P $\underline{\mathrm{DF}>}$

Joel Mwangi Kihanga, "Islamic State as a Threat to Global Peace and Security: an Analysis of the Mechanisms used by the International Community", 2015, <http://erepository.uonbi.ac.ke/bitstre am/handle/11295/94594/Kihanga Isla mic\%20state\%20as\%20a\%20threat\%20 to\%20global\%20peace\%20and\%20secu rity:\%20an.pdf?sequence $=2>$

Muhammad Munir dan Muhammad Shafiq, "Global Threat: A Comparative Analysis of Al-Qaeda and the Islamic State", IPRI Journal, Vol. XVI, No. 2., 2016.

United Nations Security Council, Report on "UN Sanctions", Special Research Report, November 2013, diakses dari $<$ http://www.securitycouncilreport.org Latf/cf/\%7B65BFCF9B-6D27-4E9C$8 \mathrm{CD3}-$ CF6E4FF96FF9\%7D/special research $r$ eport sanctions 2013.pdf>

United Nations, Unanimously Adopting Resolution 2253 (2015), Security Council Expands Sanctions Framework to Include Islamic State in Iraq and the
Levant, 17 Desember 2015, diakses dari $<$ https://www.un.org/press/en/2015/s c12168.doc.htm>

United Nations Security Council Subsidiary Organs, Security Council Committee Pursuant to Resolutions 1267 (1999), 1989 (2011) and 2253 (2015) Concerning ISIL (DA'ESH) AL-QAIDA AND ASSOCIATED INDIVIDUALS GROUPS UNDERTAKINGS AND ENTITIES diakses dari

$<$ https://www.un.org/sc/suborg/en/sa nctions/1267/aq sanctions list>

Winkler, Inga T., "Respect, Protect, Fulfill: the Implementation of the Human Right tot Water in South Africa, accessed from https://www.ingawinkler.com/uploads /4/8/6/0/48601803/respect protect $f$ ulfill.pdf

Wood, Michael C. "The Interpretation of Security Council Resolutions", Max Planck Yearbook of United Nations Law, accessed from http://www.mpil.de/files/pdf2/mpuny b wood 2.pdf

\section{Legal Documents}

Canadian Charter of Rights and Freedoms 1982.

International Covenant on Civil and Political Rights 1966.

United Nations Charter 1945.

Abousfian Abdelrazik (Applicant) v. Canada (Minister of Foreign Affairs and the Attorney General of Canada) (Respondent), Judgment, Federal Court of Canada, [2009] F.C.J. No. 656, 4 Juni 2009.

Her Majesty's Treasury (Respondent) v. Mohammed Jabar Ahmed and others (FC) (Appelants), Her Majesty's Treasury v. Mohammed Al-Ghabra (FC) (Appelant), (Respondent), $\mathrm{R}$ (on the application of Hani El Sayed Sabaei Youssef) (Respondent) v. Her Majesty's Treasury (Appelant), Judgment, United Kingdom Supreme Court, [2008] EWCA Civ 1187, 27 Januari 2010. 
Kingdom Supreme Court, [2008] EWCA

Civ 1187, 4 Februari 2010.

Nabil Sayadi dan Patricia Vinck v. Belgium, Views, United Nations Human Rights Committee, CCPR/C/94/D/1472/2006, 29 Desember 2008.

Nada v. Switzerland, Judgment, Grand Chamber of the European Court of Human Rights, Application No. 10593/08, 12 September 2012.

United Nations General Assembly to the International Court of Justice, Advisory Opinion, International Court of Justice, Reparation for Injuries Suffered in the Service of the U.N., 11 April 1949.

Yassin Abdullah Kadi (Applicant) v. Council of the European Union and Commission of the European Communities (Respondent), Judgment, European
Union Court of First Instance, T-315/01, 2009.

Judgment, European

Union Court of First Instance, T-315/01, 21 September 2005.

Security Council Resolution 1267 (1999), concerning Al-Qaida and associated individuals and entities

Security Council Resolution 2253 (2015), tentang 1267/1989/2253 ISIL (Da'esh) and Al-Qaida Sanctions List

Security Council Resolution 2255 (2015) 1267/1989/2253 ISIL (Da'esh) and AlQaida Sanctions List

Security Council Resolution 2367 (2017) 1267/1989/2253 ISIL (Da'esh) and AlQaida Sanctions List

Security Council Resolution 2368 (2017) 1267/1989/2253 ISIL (Da'esh) and AlQaida Sanctions List 